\title{
IDENTIFIKASI LOKASI RAWAN BENCANA BANJIR LAHAR DI DAERAH ALIRAN SUNGAI PABELAN, MAGELANG, JAWA TENGAH
}

\author{
Suprapto Dibyosaputro ${ }^{1}$, Henky Nugraha ${ }^{2}$, Ahmad Cahyadi $^{3}$ dan Danang Sri Hadmoko ${ }^{4}$
}

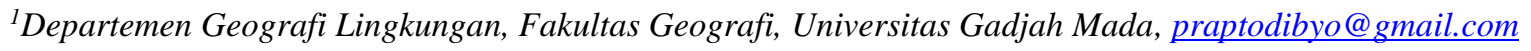

${ }^{2}$ Magister Perencanaan Pesisir dan daerah Aliran Sungai Fakultas Geografi UGM, nugrahahenky@ gmail.com

${ }^{3}$ Departemen Geografi Lingkungan, Fakultas Geografi, Universitas Gadjah Mada, ahmadcahyadi@geo.ugm.ac.id

${ }^{4}$ Departemen Geografi Lingkungan, Fakultas Geografi, Universitas Gadjah Mada, hadmoko@ugm.ac.id

\begin{abstract}
ABSTRAK
Daerah Aliran Sungai (DAS) Pabelan merupakan salah satu sungai yang paling rawan mengalami banjir lahar pascaerupsi Gunungapi Merapi tahun 2010. Kejadian banjir lahar merusak di DAS ini terjadi sebanyak 17 kali sejak erupsi tahun 2010, terbanyak kedua setelah DAS Putih. Penelitian ini bertujuan mengidentifikasi wilayah rawan banjir lahar berdasarkan pada sensus dampak banjir lahar yang terjadi pasca erupsi Merapi Tahun 2010. Sensus dilakukan dengan melakukan identifikasi lokasi yang mengalami kerusakan dengan citra penginderaan jauh resolusi tinggi di lokasi kajian. Selain itu, identifikasi dilakukan dengan wawancara dengan seluruh pemerintah tingkat dusun dan desa yang wilayahnya dilalui aliran Sungai utama Pabelan. Hasil analisis menunjukkan bahwa lokasi rawan bencana banjir lahar terdiri dari 27 titik yang tersebar mulai dari hulu sampai dengan hilir DAS Pabelan.
\end{abstract}

Kata Kunci: Lahar, Kerawanan, DAS Pabelan, Gunungapi Merapi

\section{Pendahuluan}

Salah satu bencana sekunder dari erupsi gunungapi yang menyebabkan banyak kerusakan adalah banjir lahar [1]. Banjir lahar dapat menyebabkan kerusakan bahkan sampai pada wilayah yang letaknya $200 \mathrm{~km}$ dari pusat erupsi gunungapi [2] (Gambar 1). Aliran piroklastik yang dipicu bertambahnya material fluida (missal oleh air hujan atau jebolnya danau kawah) akan sangat merusak karena memiliki massa yang besar dan kecepatan yang tinggi [3]. Lahar adalah aliran material dan air, di mana konsentrasi material minimal $60 \%$ dari total volume. Hal ini tentunya akan menyebabkan kemungkinan terjadinya luapan dari lembah sungai akibat volume aliran dapat mencapai 2,5 kali kondisi aliran sungai maksimum yang mungkin terjadi. Material aliran lahar berasal dari bongkah batuan, hancuran batuan, kerikil, pasir dan debu yang dikontrol oleh gaya gravitasi dan material berasal dari hasil letusan gunungapi.

Salah satu alasan yang menyebabkan banjir lahar menyebabkan terjadinya kerusakan yang besar adalah bahwa kejadian banjir lahar akan terus terjadi sampai material piroklastik di bagian fasies proksimal habis. Hal ini berarti dalam satu kejadian erupsi gunungapi, banjir lahar akan terjadi beberapa kali, bahkan sepanjang musim penghujan. Hal ini tentunya akan menyebabkan kerusakan yang besar karena suatu wilayah akan dihantam oleh banjir lahar beberapa kali dengan interval yang mungkin sangat berdeka$\tan$.

Salah satu gunungapi di Indonesia yang paling aktif adalah Gunungapi Merapi yang terletak di Daerah Istimewa Yogyakarta dan Provinsi Jawa Tengah [4, 5]. Kejadian erupsi yang sangat sering (kurun waktu 4 sampai 8 tahun sekali) menyebabkan banjir lahar terjadi dengan frekuensi Prosiding Seminar Nasional Geografi Lingkungan I, 27 November 2016 di Fakultas Geografi UGM Yogyakarta. Halaman 31 - 38. ISBN 978-979-8786-65-5 
yang tinggi. Salah satu sungai yang paling sering dialiri banjir lahar adalah Sungai Pabelan. Sungai yang terletak di Kabupaten Magelang ini merupakan sungai yang mengalami banjir lahar terbanyak kedua setelah Sungai Putih pasca erupsi Gunungapi Merapi tahun 2010 [6].

Tipe banjir lahar yang paling sering terjadi adalah lahar post-eruptive atau lahar yang terjadi pasca letusan [4]. Lahar yang terbentuk di sungai-sungai yang berhulu di puncak Gunungapi Merapi dipicu oleh hujan yang lebat yang terjadi di puncak [6]. Hal ini menyebabkan kejadian banjir lahar akan banyak terjadi pada bulan-bulan di mana musim penghujan terjadi [7] (Gambar 2).

Penelitian ini bertujuan untuk mengidentifikasi lokasi di DAS Pabelan yang memiliki kerawanan terhadap banjir lahar. Identifikasi didasarkan pada kejadian banjir lahar pasca erupsi Gunungapi Merapi tahun 2010. Lokasi-lokasi yang mengalami kerusakan akibat banjir lahar pada masa itu diidentifikasi sebagai lokasi yang memiliki kerawanan terhadap banjir lahar. Kajian ini akan menjadi awal untuk menentukan pola dari kerusakan banjir lahar, sehingga memunculkan indikasi-indikasi geografis yang khas yang dapat diidentifikasi sebagai wilayah yang rawan terdampak banjir lahar. Namun demikian, paper ini akan dibatasi dalam bahasan lokasi-lokasi yang rawan banjir lahar di DAS Pabelan, tanpa menganalisis karakter-karakter geografi khas dari lokasi tersebut.

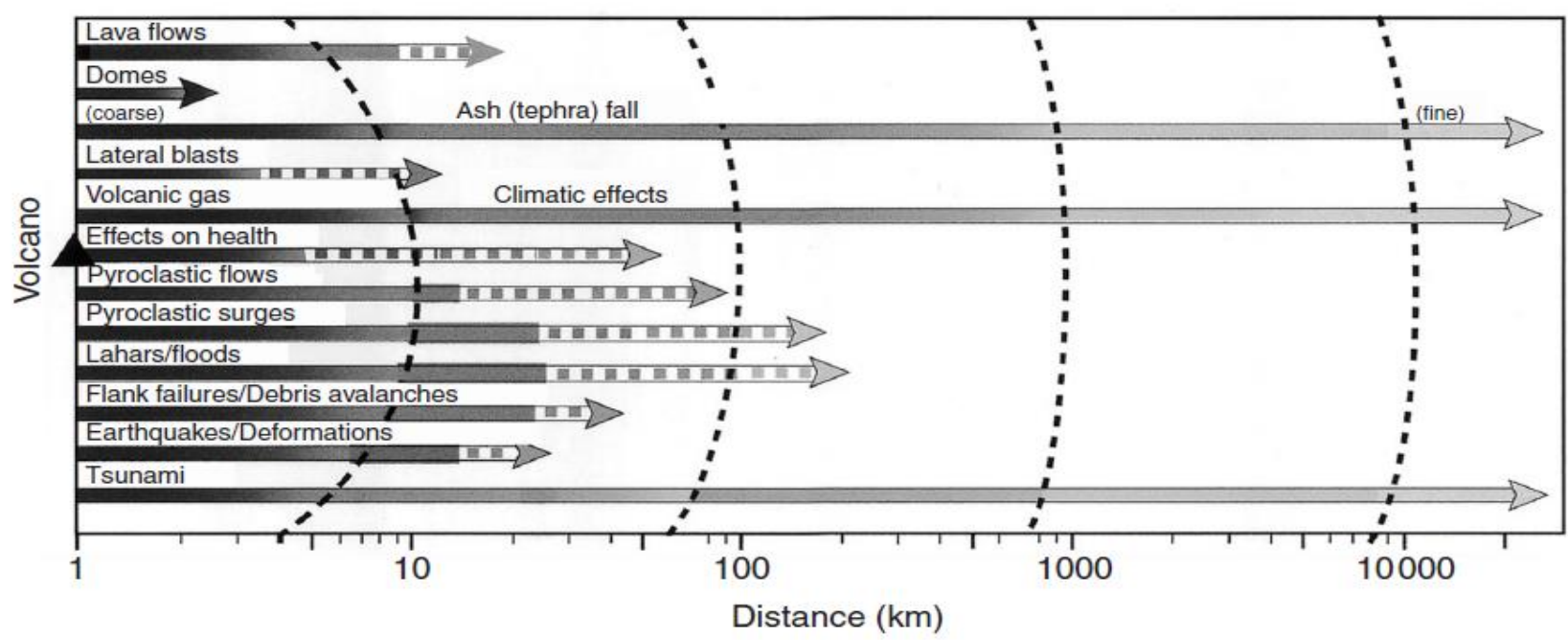

Gambar 1. Tipe bahaya yang ditimbulkan oleh letusan gunungapi berdasarkan jarak pengaruh dari puncak [2] 


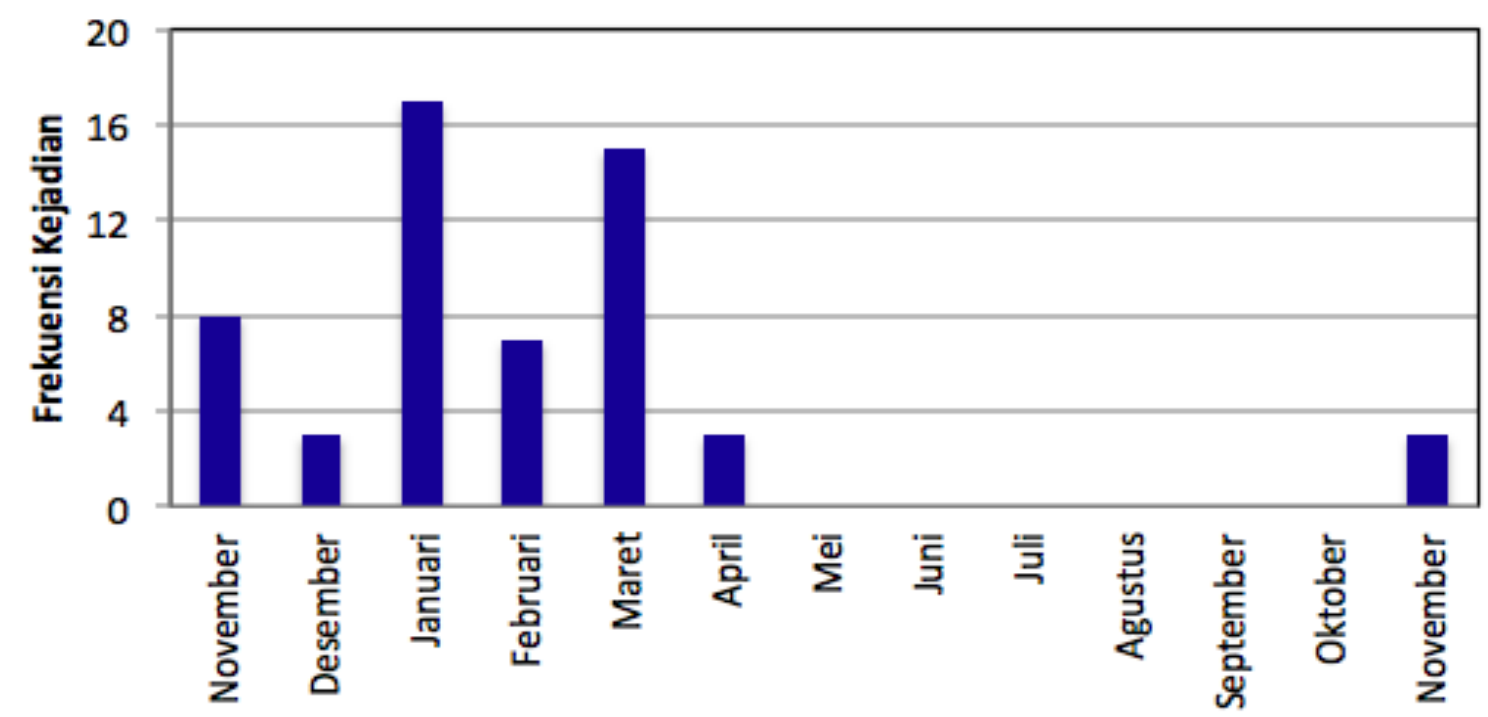

Bulan (November 2010 s.d. November 2011)

Gambar 2. Frekuensi Kejadian Banjir Lahar pada Sungai-Sungai di Gunungapi Merapi Pasca Erupsi Tahun 2010 [7]

\section{Metode Penelitian}

Identifikasi lokasi rawan bencana banjir lahar ditentukan berdasarkan keberadaan lokasi terdampak banjir lahar di DAS Pabelan (Gambar 3) pasca erupsi Gunungapi Merapi tahun 2010. Pengambilan data dilakukan secara sensus. Pengamatan lapangan yang dilakukan didasarkan pada hasil interpretasi citra penginderaan jauh resolusi tinggi tahun 2011 serta wawancara dengan perangkat pemerintahan di tingkat dusun dan desa di DAS Pabelan (Gambar 4). Hasil interpretasi dan wawancara disurvei lapangan kemudian dibuat data spasial meliputi kerusakan, karakter fisik sungai dan identitas geospasial dari lokasi.

Secara garis besar, teknis pelaksanaan penelitian ini dibagi menjadi 5 tahapan. Tahap pertama melakukan interpretasi citra resolusi tinggi yang direkam pasca erupsi Gunungapi Merapi tahun 2010. Contoh kenampakkan yang diidentifikasi ditunjukkan oleh Gambar 5. Tahap kedua dilakukan digitasi on screen pada kenampakkan yang diinterpretasi sebagai dampak banjir lahar. Data yang telah didigitasi kemudian diberikan atribut administrasi agar mudah dalam melakukan pengecekan lapangan. Tahap ketiga adalah wawancara dengan perangkat pemerintah tingkat dusun dan desa. Wawancara ini dimaksudkan untuk memvalidasi data yang sudah dihadilkan dari interpretasi citra penginderaan jauh dan melakukan pengumpulan data titik-titik yang belum teridentifikasi serta melengkapi data terkait dengan dampak yang ditimbulkan oleh banjir lahar pada masing-masing titik. Tahap keempat dilakukan pengecekan lapangan untuk melihat secara langsung kondisi lokasi yang terdampak banjir lahar dan melakukan validasi. Tahap terakhir berupa penyajian data dalam peta dan melakukan analisis hasil kajian. 


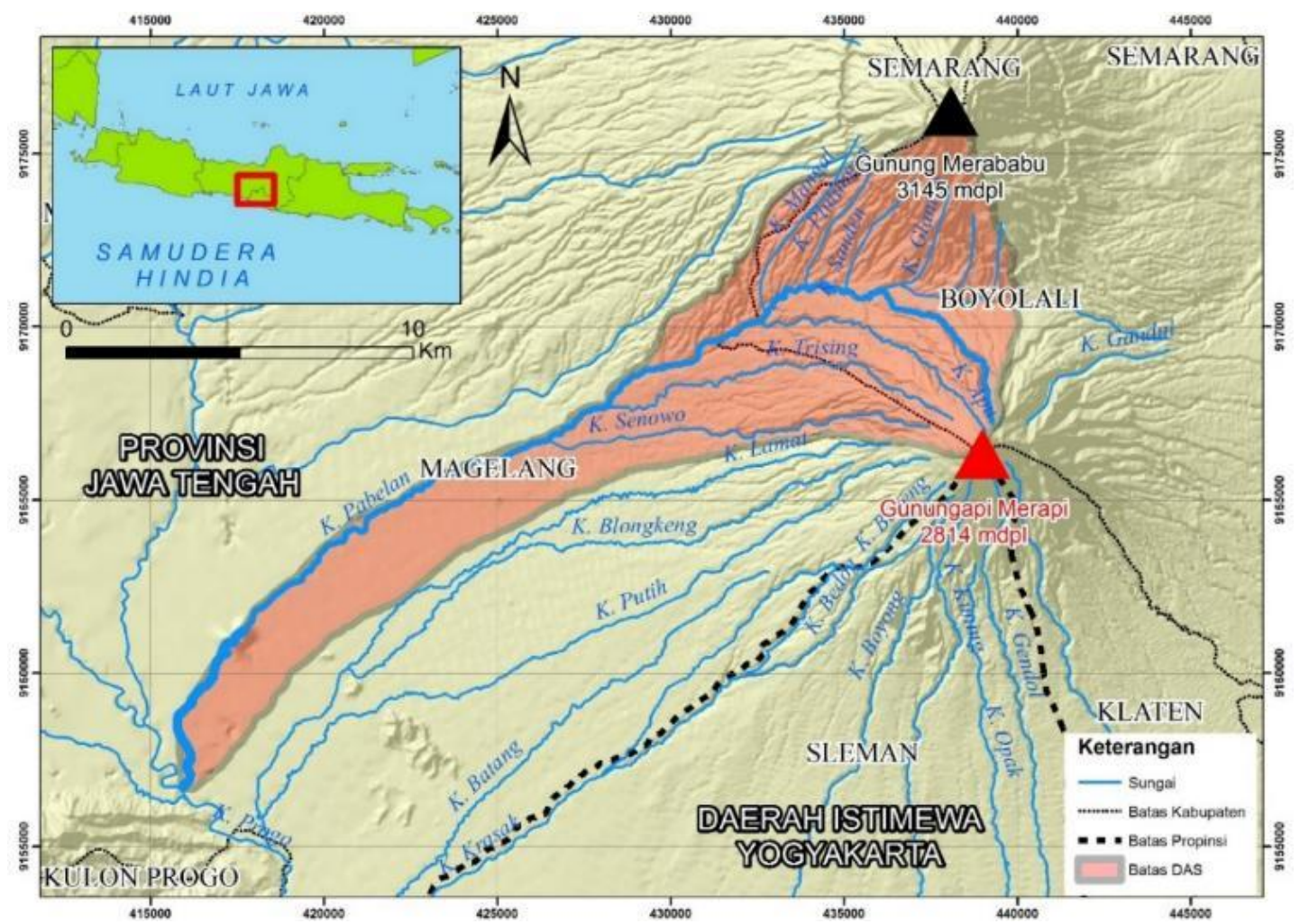

Gambar 3. Peta Lokasi DAS Pabelan, Magelang, Jawa Tengah

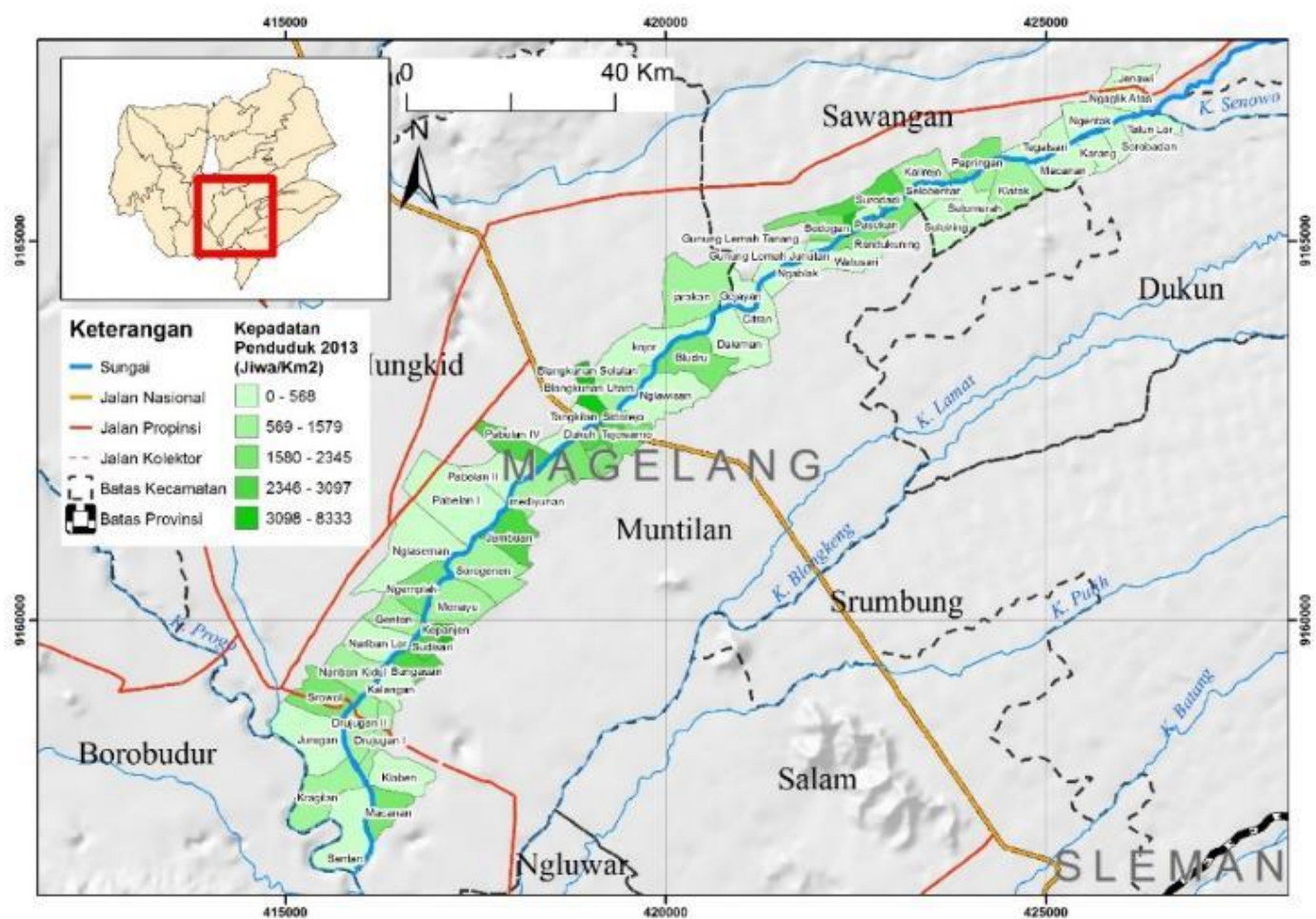

Gambar 4. Peta Dusun dan Kepadatan Penduduk di DAS Pabelan, Magelang, Jawa Tengah 


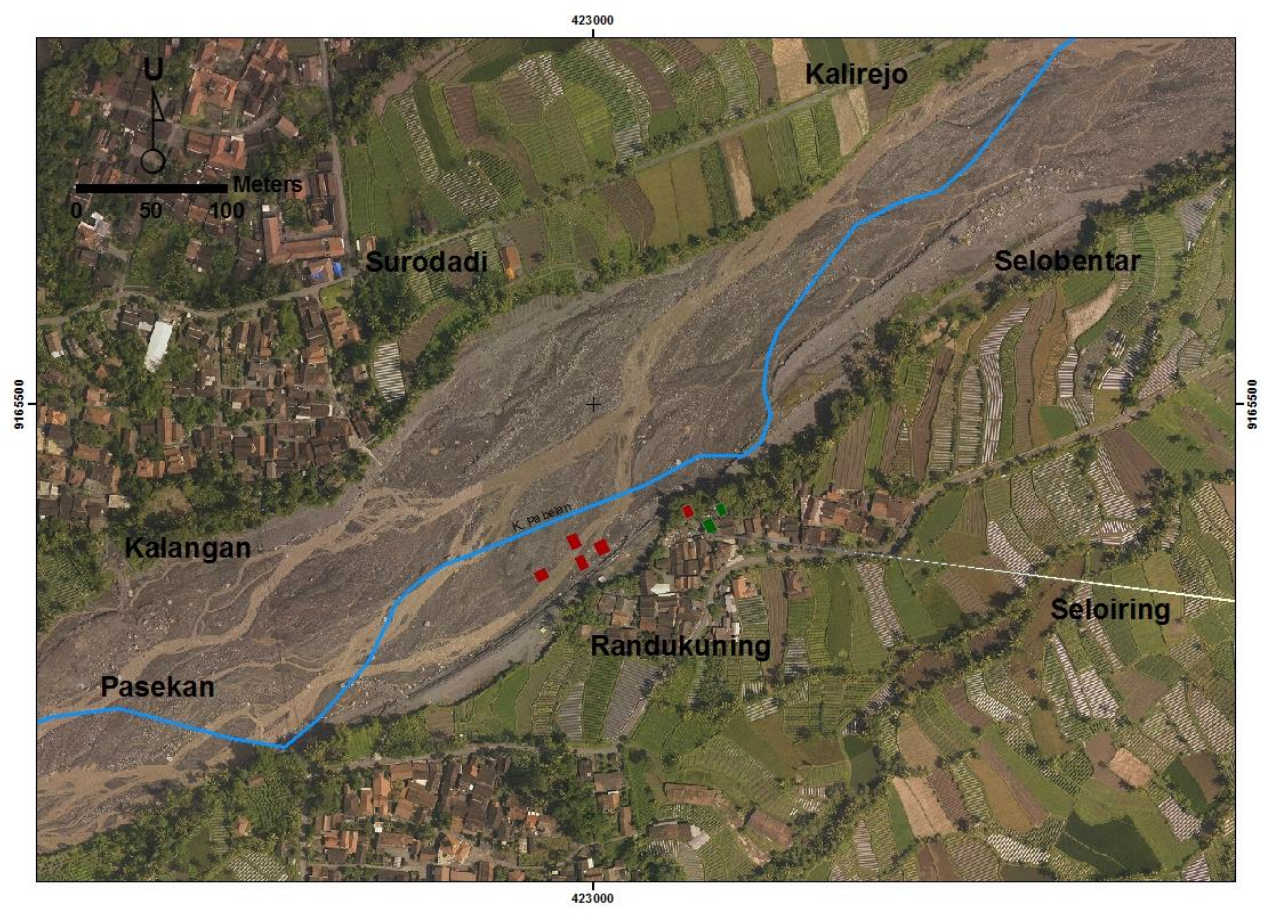

Gambar 5. Contoh Kenampakkan Lokasi Terdampak Banjir Lahar di Sungai Pabelan dalam Citra Satelit Resolusi Tinggi

\section{Hasil dan Pembahasan}

Berdasarkan hasil analisi yang telah dilakukan, diketahui bahwa terdapat 27 titik lokasi di DAS Pabelan yang memiliki kerawanan banjir lahar (Gambar 6). Lokasi ini secara morofologi terdapat pada lereng tengah Gunungapi Merapi. Berdasarkan fasiesnya, DAS Pabelan hanya menempati fasies proksimal dan medial, hanya saja dampak banjir lahar hanya nampak pada fasies medial dari Gunungapi Merapi.

Beberapa kenampakkan kerusakan pada citra satelit sangat mudah diidentifikasi sebagai kerusakan yang ditimbulkan oleh banjir lahar. Hal ini karena dampak yang ditimbulkan oleh banjir lahar nampak sebagai lahan terbuka dengan warna putih sampai dengan abu-abu khas sebagai material segar pasir piroklastik. Namun demikian, identifikasi yang dilakukan pada suatu wilayah yang terdampak banjir lahar dengan selang waktu kejadian dan pemotretan yang lama akan cukup menyulitkan. Hal ini karena material piroklastik dengan cepat akan ditumbuhi rumput dan biasanya telah mengalami perubahan akibat hasil kerja manusia. Selain itu, dampak yang sangat kecil misalnya jebolnya tanggul irigasi atau kerusakan struktur jembatan seringkali sulit diinterpretasi dengan penglihatan langsung. Oleh karena itu, maka proses wawancara dengan unit kajian yang relatif sempit misalnya dusun akan sangat membantu untuk menghasilkan data yang rinci dengan ketelitian yang tinggi.

Kerusakan yang terjadi akibat banjir lahar di DAS Pabelan meliputi kerusakan bangunan rumah (Gambar 7), kerusakan lahan pertanian dan infrastruktur seperti sabo (Gambar 8), saluran irigasi dan bending irigasi. Selain itu, terjadi pula pelebaran sungai (Gambar 9) akibat erosi pada tebing sungai akibat dari banjir lahar. Dampak yang lain adalah putusnya beberapa jembatan di DAS Pabelan, sehingga menyebabkan terputusnya koneksi antar wilayah di beberapa wilayah di DAS Pabelan. 


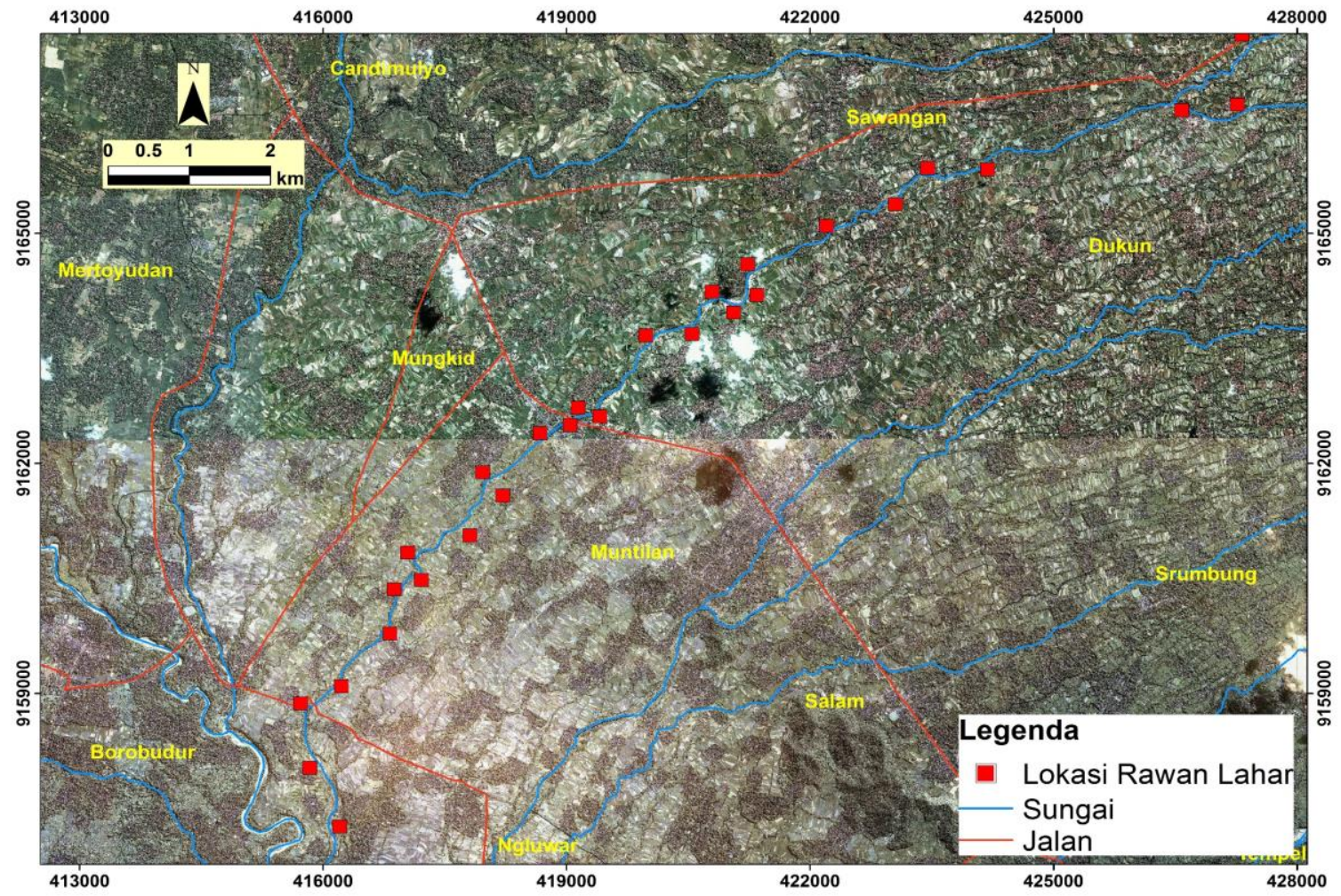

Gambar 6. Lokasi Rawan Banjir Lahar di DAS Pabelan, Magelang, Jawa Tengah

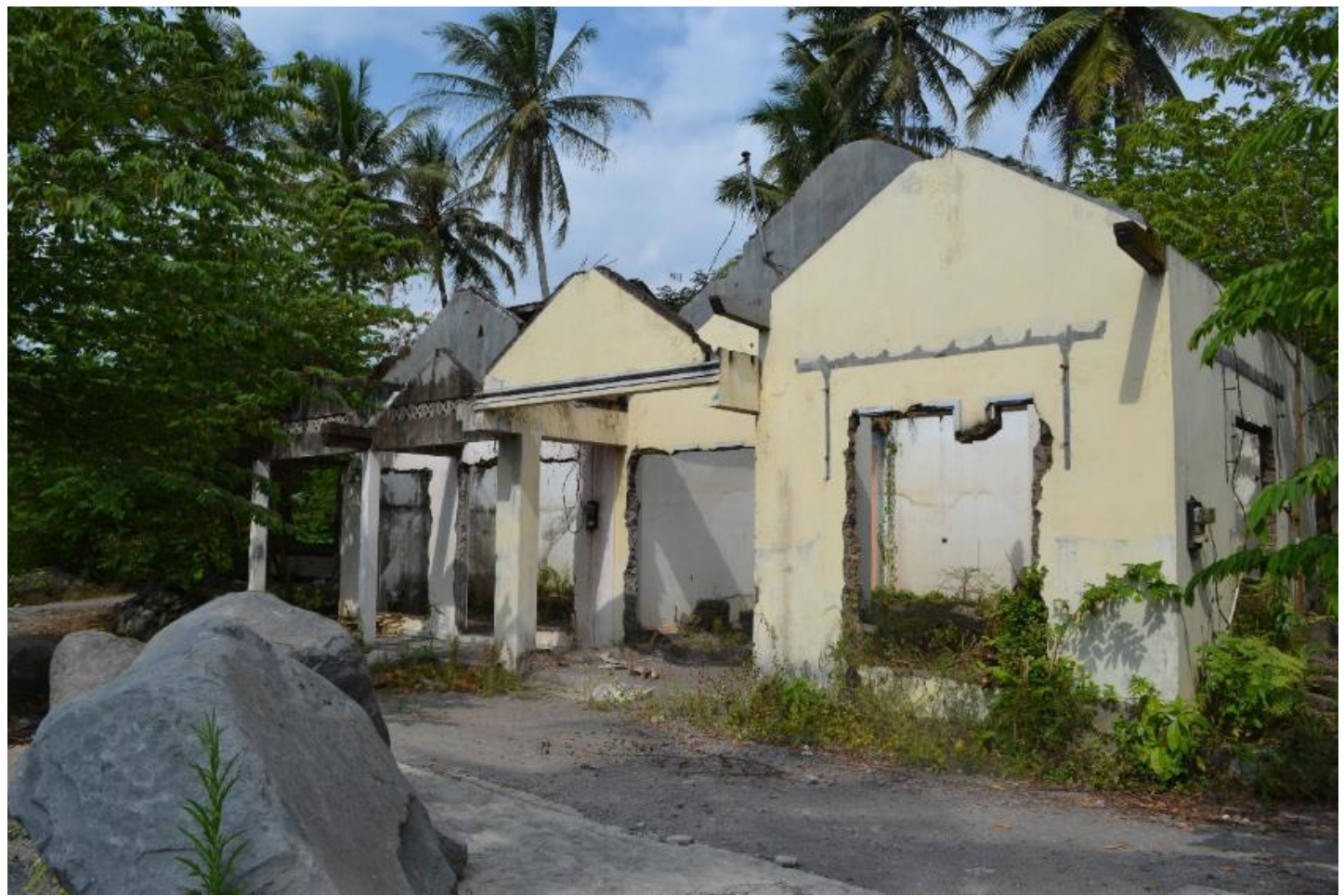

Gambar 7. Kerusakan Rumah di DAS Pabelan Akibat Banjir Lahar

Prosiding Seminar Nasional Geografi Lingkungan I, 27 November 2016 di Fakultas Geografi UGM Yogyakarta. Halaman 31 - 38. ISBN 978-979-8786-65-5 


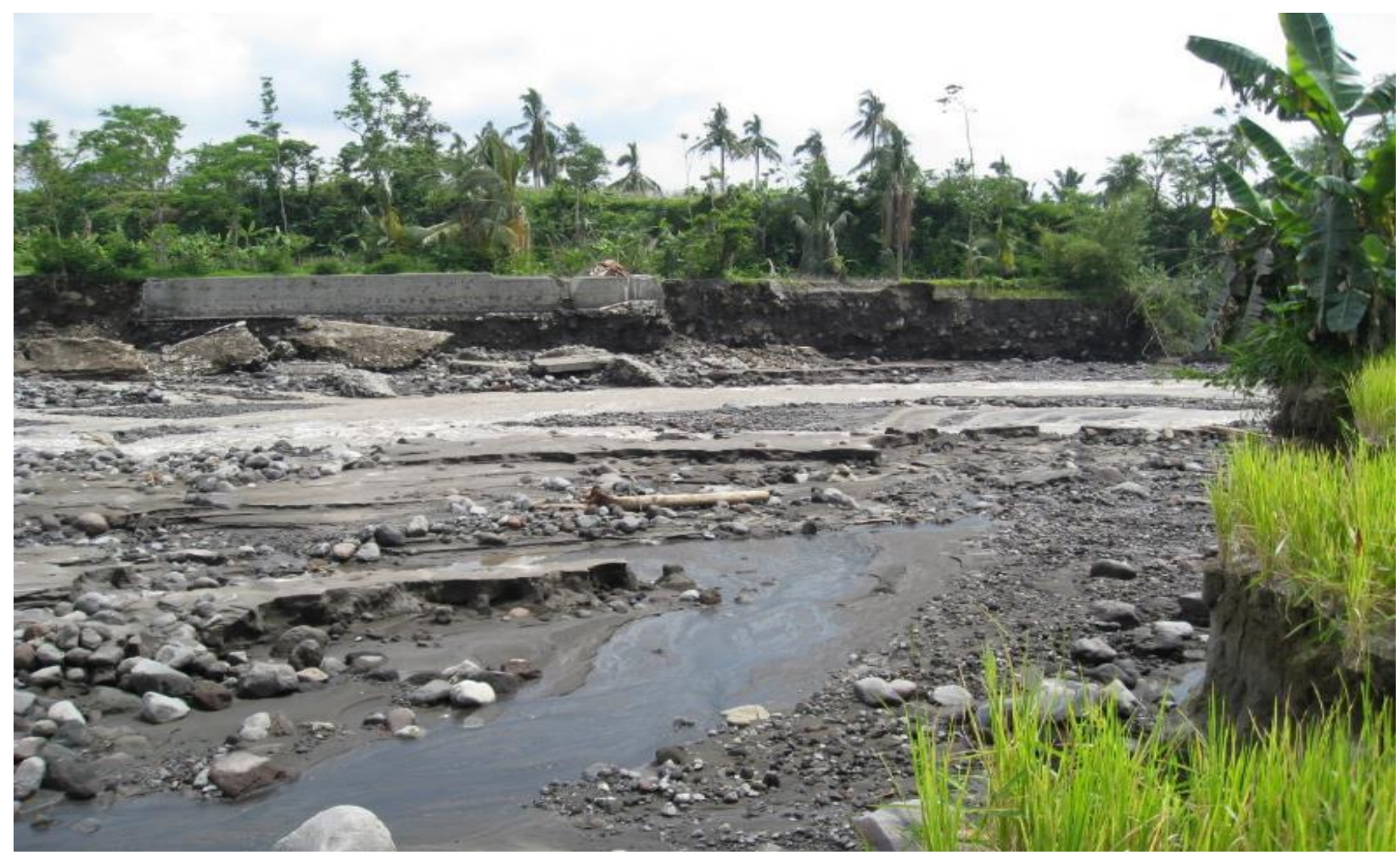

Gambar 8. Kerusakan Bangunan Sabo di DAS Pabelan Akibat Banjir Lahar

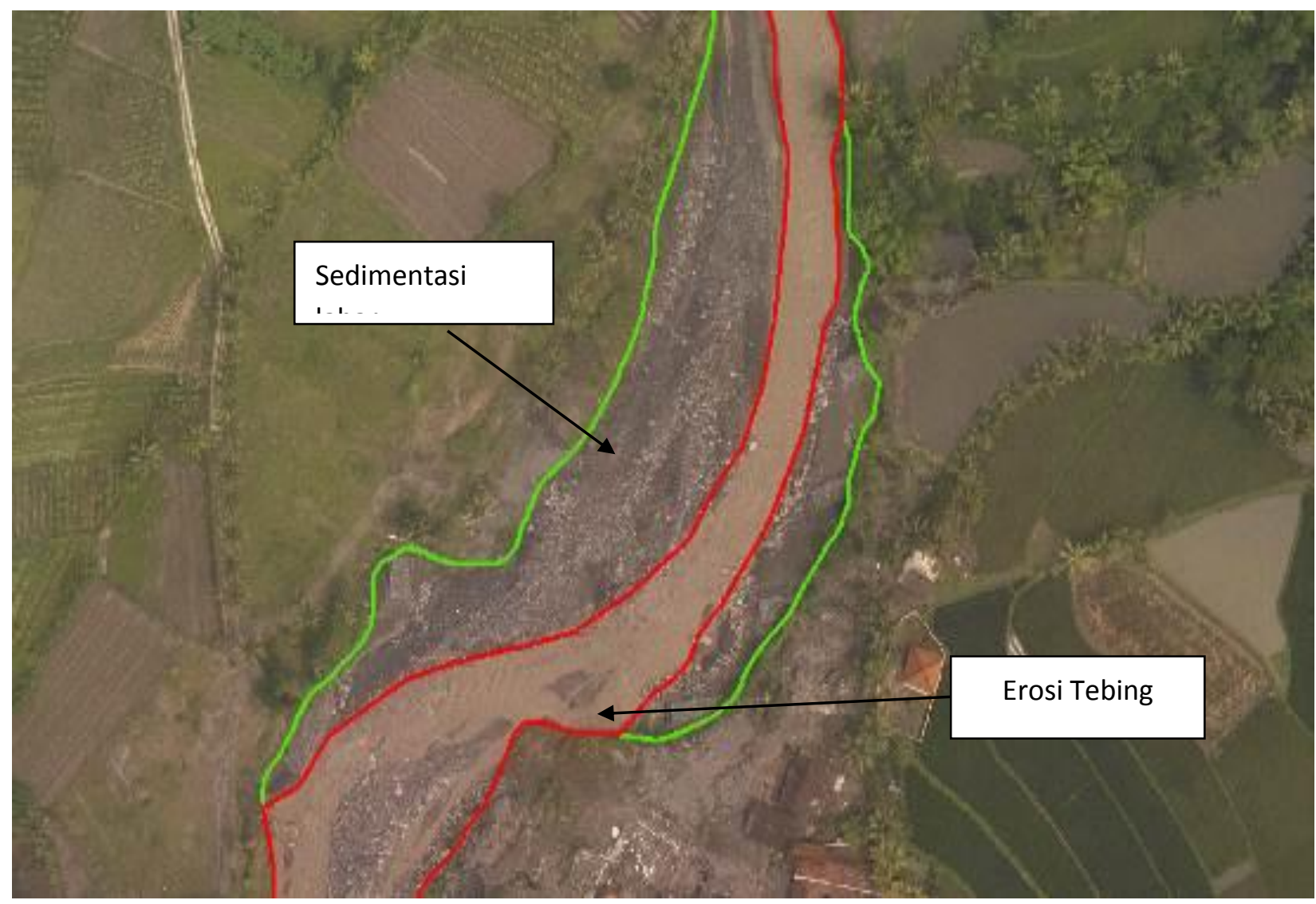

Gambar 9. Pelebaran Sungai Akibat Banjir Lahar di DAS Pabelan

Prosiding Seminar Nasional Geografi Lingkungan I, 27 November 2016 di Fakultas Geografi UGM Yogyakarta. Halaman 31 - 38. ISBN 978-979-8786-65-5 


\section{Kesimpulan}

Berdasarkan analisis yang dilakukan, maka diketahui bahwa terdapat 27 lokasi di DAS Pabelan yang memiliki kerawanan terhadap banjir lahar. Banjir lahar di DAS Pabelan menyebabkan kerusakan tempat tinggal, banguan air, jalan, lahan pertanian dan pelebaran sungai. Interpretasi citra penginderaan jauh untuk memetakan kerusakan akibat banjir lahar di DAS Pabelan memiliki akurasi yang tinggi, namun mengalami kesulitan untuk mengidentifikasi dampak yang ukurannya kecil seperti kerusakan pada bendungan irigasi dan kerusakan struktur jembatan.

\section{Pengakuan}

Penelitian ini merupakan bagian dari hibah penelitian unggulan perguruan tinggi (PUPT) tahun 2016 yang berjudul "Integrasi Kajian Kebencanaan untuk Mendukung Perencanaan Pengembangan Wilayah dan Peningkatan Kapasitas Masyarakat pada Kawasan Rawan Bencana Gunungapi”. Penelitian ini didanai oleh Direktorat Riset dan Pengabdian Masyarakat, Direktirat Jenderal Penguatan Riset dan Pengembangan, Kementerian Riset, Teknologi dan Pendidikan Tinggi sesuai Surat Perjanjian Penugasan Pelaksanaan Program Penelitian Nomor: 015/SP2H/LT/DPRM/II/2016 Tanggal 17 Februari 2016.

\section{REFERENSI}

[1] Lavigne, L., Thouret, J.C., Hadmoko, D.S., and
Sukatja, C.B., 2007. Lahars in Java: initiation, dynamics and Deposition Processes. Forum Geografi, $21(1): 17-32$.

[2] Thouret J-C (2004) Geomorphic processes and hazards on volcanic mountains. In: Owens $\mathrm{Ph}$, Slaymaker O (eds) Mountain geomorphology, chapter 11. Arnold, London, pp 242-273

[3] Smith G.A., and Fritz W.J., 1989: Penrose Conference report: Volcanic influences on terrestrial sedimentation. Geology 17: 376.

[4] Lavigne F., 1999. Lahar hazard micro-zonation and risk assessment in Yogyakarta city, Indonesia. GeoJournal 49: 173-183, 1999.

[5] Lavigne F., Thouret J.C., Voight B., Suwa H.,Sumaryono A., 2000. Lahars at Merapi volcano, Central Java: an overview. Journal of Volcanology and Geothermal Research, 100(1): 423-456.

[6] Beverage, J.P. and Culberston, J.K., 1964. Hyperconcentrations of suspended sediment. Journal of the Hydraulic Division, American Society of Civil Engineers 90, pp. 117-128.

[7] Hadmoko, D.S., Santosa, L.W., Suratman, Marfai, M.A., Widiyanto. 2011. Peranan Geomorfologi Dalam Pengurangan Risiko Bahaya Lahar. Makalah dalam Workshop Mitigasi Bencana Lahar Gunungapi Merapi Pasca Erupsi 2010.Balai Sabo-Kementrian Pekerjaan Umum 16-17 November 2011. 